\title{
Low cytotoxicity, and antiproliferative activity on cancer cells, of the plant Senna alata (Fabaceae)
}

\author{
Amir Modarresi Chahardehi ${ }^{1}$, Hasni Arsad ${ }^{1 *}$, Noor Zafirah Ismail ${ }^{1} \&$ Vuanghao Lim ${ }^{1}$ \\ 1. Integrative Medicine Cluster, Advanced Medical and Dental Institute, Universiti Sains Malaysia, 13200, Bertam, \\ Penang, Malaysia; amirmch@gmail.com, hasniarsad@usm.my, piecesnzi@gmail.com, vlim@usm.my
}

Received 04-VI-2020. C Corrected 23-XI-2020. Accepted 14-XII-2020.

\begin{abstract}
Introduction: The leaves of Senna alata from the Fabaceae family have been used in folk medicine for the cure of skin disease. In this study, we tested the extract and fractions on brine shrimp lethality test and antiproliferative activity on cancer and normal cell lines. Objective: In this study, we assessed the cytotoxicity of $S$. alata using brine shrimp test and two cell lines. Methods: The $80 \%$ ethanolic leaf extract and its fractions were examined for possible cytotoxic effect using sulforhodamine B (SRB) cytotoxicity assay towards breast cancer (MCF-7), normal (MCF10A) cell lines, and brine shrimp lethality test (BSLT). Results: The brine shrimp lethality bioassay exhibits no cytotoxicity even at high concentration $(5000 \mu \mathrm{g} / \mathrm{mL})$. The $\mathrm{LC}_{50}$ for dichloromethane, chloroform, butanol, and aqueous were $>1000 \mu \mathrm{g} / \mathrm{mL}$ (non-toxic). $\mathrm{The}^{\mathrm{IC}_{50}}$ for in vitro SRB cytotoxicity against MCF-7 for $\mathrm{n}$-hexane was $0.013 \mu \mathrm{g} / \mathrm{mL}$, which was considered highly toxic, while dichloromethane and chloroform recorded at 47.11 and $57.61 \mu \mathrm{g} / \mathrm{mL}$, respectively after 72 hours exposure time although there was no cytotoxicity found on the normal cell line. Conclusion: This study shows that $S$. alata crude ethanolic leaf extract and its fractions potentially contain significant bioactive compounds that are safe from adverse effects, which proves the therapeutic application of $S$. alata in traditional remedy.
\end{abstract}

Key words: cytotoxicity; brine shrimp; Senna alata; breast cancer.

Modarresi Chahardehi, A., Arsad, H., Zafirah Ismail, N., \& Lim, V. (2021). Low cytotoxicity, and antiproliferative activity on cancer cells, of the plant Senna alata (Fabaceae). Revista de Biología Tropical, 69(1), 317-330. DOI 10.15517/rbt. v69i1.42144

Natural products have been recognized as the source of medicinal substances and structural sustainability for several years (Beutler, 2019). The natural resources of medicinal plants are precious phytochemicals that are often employed for the treatment of different diseases (Al-Ansari et al., 2019), especially for cancer treatment. Plants as natural resources are used for several years provide potential chemical therapeutics in cancer treatment and interest in nature (Akindele et al., 2015). Hence, phytochemicals cover a wide range of chemical spaces for the discovery of drugs (Mohanraj et al., 2018). Phytochemicals have various pharmacology mechanisms, including stimulating enzymes such as glutathione transferase or preventing cell proliferation (Shareef, Ashraf, \& Sarfraz, 2016).

Over a million women with breast cancer are identified per year around the globe (Shareef et. al., 2016); therefore, breast cancer has been the second most common cause of death for women (Azamjah, Soltan-Zadeh, \& Zayeri, 2019; Levitsky \& Dembitsky, 2014). Since mammography is not available for routine screening, late stages of breast cancer are usually investigated (Shareef et al., 2016). The function of flavonoids in cancer prevention has been documented (Elsyana, Bintang, \& Priosoeryanto, 2016). Their ability and healing 
potential have been separately documented worldwide, indicating that plants could become a prospective source of new medicines (Idris, Wintola, \& Afolayan, 2019).

Cassia alata L. (also recognized as Senna alata) is a shrub that belongs to the Fabaceae family (sub-family Caesalpinioideae), which is distributed in the intertropical region (Saito et al., 2012). This plant is popularly known as the candle bush and also ringworm tree due to its folk medicine, which is referenced in the complete flower head (Hennebelle, Weniger, Joseph, Sahpaz, \& Bailleul, 2009). It is originally from Central America, primarily found in the Caribbean region, and has also been spread to several tropical climates on all continents (Hennebelle et al., 2009). Senna alata has been utilized primarily for traditional medicine against skin infection, and constipation (Elsyana et al., 2016; Hennebelle et al., 2009) and lately has been suggested for the cosmetic industry as a natural product (Elsyana et al., 2016). Extracts of $S$. alata are considered to possess antibacterial activity; however, some other antibacterial effects such as prevention bacterial adhesion and biofilm formation besides specific compounds and mechanisms of action are not discovered properly (Saito et al., 2012). This plant possesses potential insecticidal, fungicidal (Iyengar, Rama, \& Rao, 1995; Palanichamy \& Nagarajan, 1990), antiinflammatory (Abatan, 1990), antimicrobial (Ibrahim \& Osman, 1995; Khan, Kihara, \& Omoloso, 2001), wound healing (Palanichamy, Bhaskar, Bakthavathsalam, \& Nagarajan, 1991) and antitumor activity (Olarte, Herrera, Villasenor, \& Jacinto, 2013; Pamulaparthi \& Nanna, 2015; Karchesy, Kelsey, Constantine, \& Karchesy, 2016). S. alata leaf extract is traditionally used for treating any type of diseases (Olarte et al., 2013), which is rich in polyphenols and anthraquinones (Fernand et al., 2008). The extensive use of $S$. alata has been encouraged to look for its pharmaceutically significant compounds in traditional medicine in several research studies (Saito et al., 2012). Traditionally, this plant used for treatment of cancer in Cameroon (mostly breast cancer) (Tene, Tala,
Tatong, \& Tchuente, 2017). Research on plant chemistry showed that the leaves of S. alata include saponins, anthraquinones, tannins, terpenes, alkaloids, and steroids (Prasenjit, Tanaya, Sumanta, Basudeb, \& Kumar, 2016). This significant worldwide herbal medicine has been used historically as an anti-helminthic, anti-inflammatory, uterus illness (Heyde, 1990) and bacterial infection (Igoli, Igwue, \& Igoli, 2004; Panda, Padhi, \& Mohanty, 2011; Promgool, Pancharoen, \& Deachatai, 2014; Prasenjit et al., 2016).

Meyer et al. (1982) identified the brine shrimp lethality bioassay (BSLA) as a particular test that was able to detect screening the range of crude plant extracts in herbal medicine for cytotoxicity in a simple, quick and extensive bioassay for bioactive compounds of natural product (Meyer et al., 1982; Karchesy et al., 2016; Henry, 2017). The brine shrimp lethality test (BSLT) is the primary anticancer test process (Prasetyo, Sidharta, Hartini, \& Mursyanti, 2019). However, there is a significant correlation between BSLT toxicity and cytotoxicity in certain cell lines, but this approach is not unique to anticancer activity (Asnaashari et al., 2017). The previous result showed that $\mathrm{LC}_{50}$ value on brine shrimp larvae for ethanol extract of $S$. alata was $7.7 \mu \mathrm{g} / \mathrm{mL}$ (Logarto, Silva, Guerra, \& Iglesias, 2001). The previous study showed that ethanol extract brought more reliable activity than other extracts (Panda et al., 2011). In recent years, GC-MC has developed as a primary technical tool for the secondary profiling of metabolites in both plant and nonplant organisms (Kanthal, Dey, Satyavathi, $\&$ Bhojaraju, 2014). Thus, the aim of analysing $80 \%$ ethanolic extract of this study was, therefore, to detect potential chemicals and to separate the compounds and to identify them by GC-MS application (Kanthal et al., 2014). Also, the ethanolic extract of $S$. alata can cause significant toxic effects on rats due to the presence of some compounds like emodin, aloeemodin, kaempferol and rhein (Yagi, Tigani, \& Adam, 1998). Fernand and colleagues assessed the range of phenolic compounds for $S$. alata between 81.2 to $106.0 \%$ (Fernand et al., 2008). 
Therefore, the present study focused on the antioxidant, antiproliferative, and cytotoxicity induced by extract/fractions in breast cancer (MCF-7) cells and normal human mammary epithelial (MCF10A) cells.

\section{MATERIALS AND METHODS}

Plant materials: The leaves of $S$. alata were obtained from Penang Golf Resort $\left(5^{\circ} 31^{\prime} 13.8^{\prime \prime} \mathrm{N} \& 100^{\circ} 26^{\prime} 35.4\right.$ ' E) in Bertam (North of Penang State) in November 2019. The plant was identified by a botanist, and a voucher specimen kept at the Herbarium Unit, School of Biological Sciences, Universiti Sains Malaysia, Penang Island, Malaysia.

Extraction Procedure: The leaves $(3 \mathrm{Kg}$ ) of $S$. alata were thoroughly washed with double distilled water, dried at room temperature, and pulverized using a mechanical blender (Retsch, ZM200, Germany) at Cluster of Integrative Medicine Laboratory, Advanced Medical and Dental Institute, Universiti Sains Malaysia. Then the powder plants weighed $100 \mathrm{~g}$ in each Erlenmeyer flask. Each flask was macerated with hydroalcoholic ( $80 \%$ ethanol) containing $400 \mathrm{~mL}$ of solvent. Maceration was done for three days with mechanical stirring (Bioteck, Elx808) with a constant speed of $150 \mathrm{rpm}$. The solvent changed daily with a new hydroalcoholic solvent, and residues were macerated in the respective solvent for the next day to reach exhaustive extraction (up to 3 days). After maceration, filtration was performed using Whatman filter paper $(150 \mathrm{~mm})$. The rotavapor (Eyela, Japan) was used to concentrate the total filtrate of alcoholic extract to dryness. The concentrated extract was removed from the round bottom flask into a weighed small glass bottle as crude $80 \%$ ethanolic extract. This crude extract was then fractioned by liquidliquid extraction using separation funnel and resulted in n-hexane, dichloromethane, chloroform, butanol, and aqueous fractions. Vacuum evaporator was used to evaporate each of the extract and fractions. The concentrated extracts were frozen at $-2{ }^{\circ} \mathrm{C}$ until further application.
The yield of each extract was measured and kept until further use. Fifty milligrams of dried samples from maceration, including crude 80 $\%$ ethanol extract, n-hexane, dichloromethane (DCM), chloroform, butanol and aqueous were dissolved with $100 \%$ DMSO in $1 \mathrm{~mL}$ tube, then sonicated to dissolve the dried samples.

ABTS scavenging activity: The antioxidant activity of various concentration (10, $5,2.5,1.25,0.625,1563,0.078 \mathrm{mg} / \mathrm{mL})$ of S. alata $80 \%$ ethanol extract and Trolox was determined by using ABTS assay. ABTS free radical scavenging was carried out as previously explained (Re et al., 1999). Firstly, the stock solutions of $7 \mathrm{mM}$ ABTS solution and 2.45 $\mathrm{mM}$ of potassium persulfate solution was prepared and combined to make the working solution $\mathrm{ABTS}^{\circ+}$ at an 8:12 (v/v) ratio. Then was maintained in the dark at room temperature for 16 to $18 \mathrm{~h}$. The solution was then blended by mixing 4.0-4.5 mL ABTS radical solution with $250 \mathrm{~mL}$ distilled water to give an absorbance of $0.70 \pm 0.02$ at $734 \mathrm{~nm}$. Next, $100 \mu \mathrm{L}$ extract $(0.078$ to $10 \mathrm{mg} / \mathrm{mL})$ in absolute ethanol was applied to $180 \mu \mathrm{L}$ of $\mathrm{ABTS}^{\circ+}$ working reagent in a 96-well plate. At room temperature, for 45 minutes the 96-well plate was incubated, and the absorbance was recorded at $734 \mathrm{~nm}$. Triplicate tests have been performed. The scavenging capacity was analyzed as a scavenging activity.

Scavenging activity (\%)

$$
\frac{\text { OD control-OD sample }}{O D \text { sample }}
$$

The percentage of ABTS extract scavenging activity was compared with the percentage of Trolox. A graph of percent inhibition against concentration was used to establish $\mathrm{IC}_{50}$.

Gas chromatographic-mass spectrometry (GC-MS) analysis for crude extract: Elmer Clarus Mass Spectrometer together with the Agilent Gas Chromatography (Santa Clara, CA, U.S.A.) was performed for GC-MS to analyze the $80 \%$ ethanol extract. A $10 \mu \mathrm{L}$ syringe was used to inject one microliter $(1 \mu \mathrm{L})$ into 
the chromatogram system. The Helium gas transported the analyte in the column at a flow rate of $1.2 \mathrm{~mL} / \mathrm{min}$. During the examination, a split ratio of 5:1 was performed. Temperature of the injector has been scheduled at $220{ }^{\circ} \mathrm{C}$. The analytes are extracted from capillary column model Agilent 19091S-433 with HP-5MS, $0.25 \mathrm{~mm} \times 30 \mathrm{~m} \times 0.25$ film width. Initially the temperature of the oven had been adjusted at 70 ${ }^{\circ} \mathrm{C}$ for $2.00 \mathrm{~min}$, heating up to $280^{\circ} \mathrm{C}$ at $10^{\circ} \mathrm{C} /$ min. It took $32.5 \mathrm{~min}$ overall. The energy used for ionisation was $60.922 \mathrm{eV}$. Mass measurement was conducted at $300{ }^{\circ} \mathrm{C}$. Identification of compounds was achieved by contrasting the mess spectra with the MS library.

Brine shrimp lethality test (BSLT): The cytotoxicity activity of extract and fractions was used using BSLT method. This test was performed following the mentioned protocol by Meyer et al. (1982) and McLaughlin, Rogers, \& Anderson (1998) with a bit modification. The larvae of brine shrimp were used as research specimen. Cysts were put and hatched at room temperature for 48 hours with a continuous supply of oxygen, and there is a lamp above the tank's open side which attracts the hatched shrimps near the wall of the tank, and then incubate for $25-27^{\circ} \mathrm{C}$. The shrimp became matured as nauplii after 48 hours and ready for the experiment. The artificial seawater has been prepared to produce a $38 \mathrm{~g} / \mathrm{L}$ concentration by dissolving the sea salt, then the unwanted particles were extracted to eliminate them. The number of dead and surviving brine shrimp nauplii was calculated in every well after 6 and 24 hours of incubation under light. Potassium dichromate was dissolved in artificial seawater as a positive control, functioned like a positive control between 0.01 to $3.00 \mu \mathrm{g} / \mathrm{mL}$ concentrations. Larvae from the first day were transferred to the 24 -well plates (10 per each well). All the extract and fractions dissolved in saline water and dimethyl sulfoxide (DMSO). As a negative control, a saline media containing DMSO (1\%) were used. Ten nauplii are counted under a dissecting microscope (Meiji Techno, 10X) and then transferred with the aid of Pasteur pipette to each well; for each well a volume of $2 \mathrm{~mL}$ has been retained in order to achieve the required concentration for extract. The experiment performed nine concentration of samples $(5000,2500,1250,625,312,156$, 78.1, 39.06, $19.50 \mu \mathrm{g} / \mathrm{mL})$. Each concentration was conducted in three replicates. When larvae did not show any motion for 10 seconds of monitoring, they were supposedly dead (Meyer et al., 1982). Samples of $\mathrm{LC}_{50}$ (lethal concentration $50 \%$ ) higher than $1000 \mu \mathrm{g} / \mathrm{mL}$ is found to be toxic to brine shrimp. The surviving larvae were recorded after 6 and 24 hours of sample exposure. Statistical analysis was used to determine the mortality rate and the lethal concentrations of $S$. alata extract resulting to $50 \%$ mortality of the brine shrimp $\left(\mathrm{LC}_{50}\right)$.

Mortality rate (\%)

$\frac{\text { Total naupii-Alive naupii }}{\text { Total naupii }}$

Cytotoxicity using Sulforhodamine B (SRB) assay: Sulphorhodamine B (SRB) assay has been used to determine the cytotoxicity activity of $S$. alata extracts using breast carcinoma cell line (MCF-7) and normal human mammary epithelial cells (MCF10A) from American Type Culture Collection (ATCC, Manassas, VA, USA). MCF-7 and MCF10A cell lines were cultured in RPMI 1640 and Dulbecco's Modified Eagle Medium (DMEM) medium, respectively, containing $10 \%(\mathrm{v} / \mathrm{v})$ fetal bovine serum (FBS) and $1 \%(\mathrm{v} / \mathrm{v})$ penicillin-streptomycin (PS) (Invitrogen Co., Carlsbad, CA, USA). Briefly, $1 \times 10^{4}$ cells/well of MCF-7 and MCF10A were separately seeded in 96-well plates in a triplicate row and loaded $100 \mu \mathrm{L}$ culture medium (RPMI 1640 and DMEM, for MCF-7 and MCF10A cell lines, respectively). Microplates were incubated at 37 ${ }^{\circ} \mathrm{C}, 5 \% \mathrm{CO}_{2}, 95 \%$ air, and humidity about 100 $\%$. On the following day, the cells were treated with seven concentrations of extracts $(0,9.38$, $18.75,37.50,75.00,150.00$, and $300.00 \mu \mathrm{g} / \mathrm{mL}$ ) for 24, 48, and $72 \mathrm{hrs}$. Following these hours, the plate containing extract concentration was 
incubated, and finally, the test ended by adding cold TCA. $50 \mu \mathrm{L}$ of cold $30 \%$ (w/v) TCA (at final concentration, $10 \%$ TCA) was applied for in-situ cell fixation with incubation at $4{ }^{\circ} \mathrm{C}$ for 30 minutes. Then, the supernatant solution has been discarded, microplates were rinsed with tap water five times and kept for air-dried. Sulforhodamine B (SRB) $(50 \mu \mathrm{L})$ at $0.4 \%(\mathrm{w} / \mathrm{v})$ in $1 \%$ acetic acid was loaded and incubated for 30 minutes at room temperature. Once staining is finished, loose dyes have been retrieved, and the remaining dyes have been removed using five times washing with $1 \%$ acetic acid. After the plates were air-dried at room temperature, and then bounded stain with a $10 \mathrm{mM}$ Tris base. The optical density (OD) of the plate wells has been measured with a microplate reader (Biotek, Elx808) at $570 \mathrm{~nm}$, and the data were held. The percentage survival (viability) of treated cells over the control cells $\times 100(T / C)$ was calculated as cell viability.

$\%$ Cell viability

$$
\frac{O D(\text { test sample)-OD (blank) }}{O D(\text { Control })-O D(\text { blank })} \times 100
$$

A linear regression of absorbance against the examined concentrations was calculated the concentration at which cell proliferation is inhibited by $50 \%\left(\mathrm{IC}_{50}\right)$.

Cell imaging: The high-resolution cell microscopes were demonstrated after 72 hours of incubation of cancer cell line and 24 hours for normal cell line, capturing and tracking images using an inverted phase-contrast microscope (Olympus, CKX41) of each concentration for clearly visible cell viability and cell morphology evaluation.

Statistical analysis: Statistical analysis was performed using GraphPad Prism Ver.8 (GraphPad Software, 1996). The means of three replicates are shown in all analytical data (mean \pm standard deviation). $\mathrm{P} \leq 0.05$ was considered statistically significant.

\section{RESULTS}

The residue of the plant was then extracted with n-hexane, dichloromethane (DCM), chloroform, butanol and water (aqueous) subsequently in the same way to give $80 \% \mathrm{EtOH}$ (10.9 \%, yield: $43.9 \mathrm{~g})$, n-hexane $(0.22 \%$, yield: $0.89 \mathrm{~g}), \mathrm{DCM}(0.05 \%$, yield: $0.18 \mathrm{~g})$, chloroform (0.02\%, yield: $0.09 \mathrm{~g})$, butanol $(0.13 \%$, yield: $0.51 \mathrm{~g})$ and aqueous $(0.16 \%$, yield: $0.65 \mathrm{~g}$ ) for using $400 \mathrm{~g}$ powder leaves of $S$. alata. This study demonstrates that the ABTS assay $\mathrm{IC}_{50}$ values of Trolox as positive control and $80 \%$ ethanol extract were 0.092 \pm 0.02 and $5.59 \pm 1.50 \mathrm{mg} / \mathrm{mL}$, respectively (Table 1).

TABLE 1

Antioxidant activity of $80 \%$ ethanolic extract of $S$. alata using ABTS assay

\begin{tabular}{lcc} 
& \multicolumn{3}{c}{ ABTS (Radical scavenging assay) $\mathrm{mg} / \mathrm{mL}$} \\
& $80 \%$ Ethanol extract & Trolox \\
IC $_{50}$ value & $5.59 \pm 1.50$ & $0.092 \pm 0.02$ \\
\hline
\end{tabular}

The findings of the GC-MS study of Senna alata ethanolic extract contribute to many compounds being identified. The mass spectrometry attached to the GC classifies these substances. The GC-MS spectrum and the potential cytotoxicity of $80 \%$ ethanol extract (crude extract) to evaluate the biomass chemical groups revealed the existence of various compounds with different retention time, as shown in Fig. 1 and Table 2.

The big fragments of the compound into small compounds lead to peaks with varying ratios of $\mathrm{m} / \mathrm{z}$. These mass spectra are the compound fingerprint detectable in the data library.

In this analysis, the formula and structure of 20 biomolecules can be predicted. Further study can proceed to the isolation of bioactive compounds, and their structural clarification and evaluation and screening of pharmaceutical activity will be useful for further drug research. GC-MS investigated steroids ( $\mathrm{\gamma}$-sitosterol), linear alkanes (undecane, octadecane, eicosane), esters (ethylparaben, 


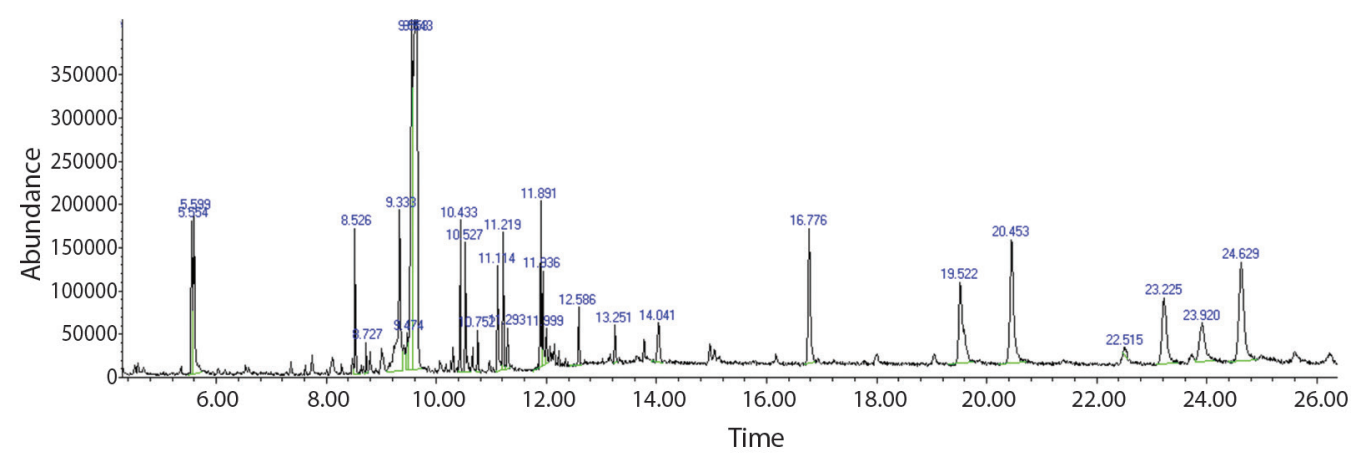

Fig. 1. GC-MC chromatogram of $80 \%$ ethanolic extract of Senna alata.

TABLE 2

Compound investigated in the $80 \%$ ethanol extract of Senna alata in GC-MS

\begin{tabular}{|c|c|c|c|c|c|}
\hline RT & Name of compound & $\begin{array}{l}\text { Molecular } \\
\text { formula }\end{array}$ & $\begin{array}{c}\text { Molecular } \\
\text { weight }(\mathrm{g} / \mathrm{mol})\end{array}$ & Percentage & $\begin{array}{l}\text { Compound } \\
\text { nature }\end{array}$ \\
\hline 5.32 & 1,3,5-Triazine-2,4,6,-triamine & $\mathrm{C}_{3} \mathrm{H}_{6} \mathrm{~N}_{6}$ & 126.11 & 80 & Cyanamide \\
\hline 5.59 & Undecane & $\mathrm{C}_{11} \mathrm{H}_{24}$ & 156.31 & 94 & Alkane \\
\hline 7.73 & Phenol,2-propyl- & $\mathrm{C}_{9} \mathrm{H}_{12} \mathrm{O}$ & 136.19 & 87 & Phenylpropanes \\
\hline 8.52 & Cycloheptasiloxane, tetradecamethyl- & $\mathrm{C}_{14} \mathrm{H}_{42} \mathrm{O}_{7} \mathrm{Si}_{7}$ & 519.07 & 91 & Cyclomethicone \\
\hline 8.72 & Ethylparaben & $\mathrm{C}_{8} \mathrm{H}_{8} \mathrm{O}_{3}$ & 152.15 & 93 & Ester \\
\hline 8.79 & Benzoic acid, 4-ethoxy, ethyl ester & $\mathrm{C} 11 \mathrm{H} 14 \mathrm{O} 3$ & 194.23 & 87 & Ester \\
\hline 9.00 & Beta-D-Glucopyranoside, methyl & $\mathrm{C}_{7} \mathrm{H}_{14} \mathrm{O}_{6}$ & 194.18 & 80 & Glucoside \\
\hline 10.43 & Cyclononasiloxane, octadecamethyl- & C18H54O9Si9 & 667.40 & 91 & Polysiloxane \\
\hline 10.96 & Hexadecanoic acid, methyl ester & $\mathrm{C}_{17} \mathrm{H}_{34} \mathrm{O}_{2}$ & 270.45 & 93 & Ester \\
\hline 11.11 & n-Hexadecanoic acid & $\mathrm{C}_{16} \mathrm{H}_{32} \mathrm{O}_{2}$ & 256.42 & 97 & Saturated fatty acid \\
\hline 11.28 & Hexadecanoic acid, ethyl ester & $\mathrm{C}_{18} \mathrm{H}_{36} \mathrm{O}_{2}$ & 284.47 & 93 & Ester \\
\hline 11.88 & Phytol & $\mathrm{C}_{20} \mathrm{H}_{40} \mathrm{O}$ & 296.50 & 90 & Alcohol \\
\hline 12.00 & 9,12,5-octadecatrienoic acid, methyl ester & $\mathrm{C}_{19} \mathrm{H}_{32} \mathrm{O}_{2}$ & 292.50 & 83 & Ester \\
\hline 12.06 & Octadecanoic acid & $\mathrm{C}_{18} \mathrm{H}_{36} \mathrm{O}_{2}$ & 284.48 & 95 & Saturated fatty acid \\
\hline 16.76 & Octadecane & $\mathrm{C}_{18} \mathrm{H}_{38}$ & 254.50 & 96 & Alkane \\
\hline 16.77 & Eicosane & $\mathrm{C}_{20} \mathrm{H}_{42}$ & 282.50 & 98 & Alkane \\
\hline 19.04 & Beta-tocophenol & $\mathrm{C}_{28} \mathrm{H}_{48} \mathrm{O}_{2}$ & 416.70 & 83 & Tocopherol \\
\hline 19.50 & Eicosane & $\mathrm{C}_{20} \mathrm{H}_{42}$ & 282.50 & 91 & Alkane \\
\hline 20.44 & Vitamin E & $\mathrm{C}_{29} \mathrm{H}_{50} \mathrm{O}_{2}$ & 430.71 & 97 & Tocopherol \\
\hline 24.62 & Gamma.sitosterol & $\mathrm{C}_{29} \mathrm{H}_{52} \mathrm{O}_{2}$ & 432.70 & 98 & Steroid \\
\hline
\end{tabular}

benzoic acid, hexadecanoic acid, ethyl ester, hexadecanoic acid, methyl ester), tocopherol (vitamin $\mathrm{E}$ and $\beta$-tocopherol) as well as fatty acid such as n-hexadecanoic acid and octadecanoic acid in the $80 \%$ EtOH extract.

Only two hours after an interaction with the higher potassium dichromate concentration, there was a fatal effect in the brine shrimp. The $\mathrm{LC}_{50}$ value for potassium dichromate was
$43.76 \mu \mathrm{g} / \mathrm{mL}$ for the corresponding regression line and showed toxic signs $\left(\mathrm{LC}_{50}\right.$ against the brine shrimp was less than $1000 \mu \mathrm{g} / \mathrm{mL}$ ). Due to high toxicity on $A$. salina cysts, potassium dichromate has shown limited hatching success. The median lethal concentration of the brine shrimp lethality assay $\left(\mathrm{LC}_{50}\right)$ for Senna alata leaf extract/fractions are shown in Table 3. 
TABLE 3

Cytotoxicity activity of various extracts of Senna alata on brine shrimp

\begin{tabular}{l|cc} 
& \multicolumn{2}{c}{$\mathrm{LD}_{50}(\mu \mathrm{g} / \mathrm{mL})$} \\
\multicolumn{1}{c|}{ Extract/fraction } & $6 \mathrm{hrs}$ & $24 \mathrm{hrs}$ \\
& $($ acute $)$ & (chronic) \\
\hline $80 \%$ EtOH (Crude extract) & $\mathrm{ND}$ & $\mathrm{ND}$ \\
Hexane & $\mathrm{ND}$ & $\mathrm{ND}$ \\
Dichloromethane & $\mathrm{ND}$ & 1432 \\
Chloroform & 2520 & 1214 \\
Butanol & 1447 & 1034 \\
Aqueous & 5053 & 2428 \\
\hline
\end{tabular}

$\mathrm{ND}=$ not determined; $\mathrm{LD}_{50}$ value for potassium dichromate was $43.76 \mu \mathrm{g} / \mathrm{mL}$.

Note: The brine shrimp mortality percentage were measured as mean $\pm \mathrm{SD}$.

Of the six extracts tested, 2 exhibited no toxicity to the brine shrimps. These included 80 $\%$ ethanolic crude extract and n-hexane fraction, in which no mortality was observed during screening. Dichloromethane, chloroform, butanol, and aqueous fractions showed an $\mathrm{LC}_{50}$ value higher than $1000 \mu \mathrm{g} / \mathrm{mL}$. There was no cytotoxic effect on any of the concentrations of the candle bush $80 \%$ ethanol extract and hexane fraction using the BSLT method and, brine shrimp were still moved vigorously. However, the other four extracts showed practically nontoxic $\left(\mathrm{LC}_{50}>1000 \mu \mathrm{g} / \mathrm{mL}\right)$ to brine shrimps. These extracts were aqueous, dichloromethane, chloroform, and butanol with $\mathrm{LC}_{50}$ values between 1 034-2 $428 \mu \mathrm{g} / \mathrm{mL}$ (after $24 \mathrm{hrs}$ ).
In the present study, the cytotoxic effect $\left(\mathrm{IC}_{50}\right)$ of the crude ethanol and fractioned extracts (hexane, dichloromethane, chloroform, butanol and aqueous) were identified on one human cancer cells (MCF-7) and one normal non-cancer cells (MCF10A) using the SRB assay. $80 \%$ EtOH extract did not show toxicity on both cell lines (Fig. 2A). Hexane fraction of $S$. alata exhibited an excellent inhibition towards MCF-7 cells with $\mathrm{IC}_{50}$ of $0.013 \mu \mathrm{g} / \mathrm{mL}$ at $72 \mathrm{~h}$, in comparison to $\mathrm{IC}_{50}$ values of $48 \mathrm{~h}$ (Fig. 2B). It is interesting to note that this fraction did not show cytotoxicity against MCF-7 cells at 24 hours. Others, such as dichloromethane and butanol against MCF-7 cell line after 72 hours with $\mathrm{IC}_{50}$ values of 47.11 and 57.61 $\mu \mathrm{g} / \mathrm{mL}$, respectively, have been shown to have significant cytotoxic activity (Table 2; Fig. 2B, Fig. 2C, Fig. 2E). Generally, the $80 \% \mathrm{EtOH}$, chloroform, and aqueous exhibited weaker cytotoxicity profile against the MCF-7 cell line $\left(\mathrm{IC}_{50}>100 \mu \mathrm{g} / \mathrm{mL}\right)$. The viability of untreated control cells corresponds to $100 \%$ because all extracts had no cytotoxic effect on the normal cell, though we did not analyze the selectivity index (SI). Although, most importantly, all the extracts did not show the cytotoxic effect on MCF10A as normal human mammary epithelial cells. In addition, $\mathrm{IC}_{50}$ values were determined for SRB assay, extracts and the results are tabulated (Table 4), and also in Fig. 2.

Treated cells were observed for the morphological feature using a bright-field

TABLE 4

Inhibition concentration $\left(\mathrm{IC}_{50}\right)$ of various extracts of Senna alata against breast cancer (MCF-7) and normal human mammary epithelial cells (MCF10A)

\begin{tabular}{lcccc} 
& & MCF-7 & MCF10A \\
Extract/fraction & & & $\mathrm{IC}_{50}(\mu \mathrm{g} / \mathrm{mL})$ & \\
& $24 \mathrm{hrs}$ & $48 \mathrm{hrs}$ & $72 \mathrm{hrs}$ & $24 \mathrm{hrs}$ \\
Hexane & $>100$ & $>100$ & $>100$ & $\mathrm{ND}$ \\
Dichloromethane & $\mathrm{ND}$ & 9.626 & 0.013 & $\mathrm{ND}$ \\
Chloroform & $>100$ & 60.03 & 47.11 & $\mathrm{ND}$ \\
Butanol & $>100$ & $>100$ & $>100$ & $\mathrm{ND}$ \\
Aqueous & 89.30 & 41.98 & 57.61 & $\mathrm{ND}$ \\
\hline
\end{tabular}

$\mathrm{ND}=$ not detected. 
A

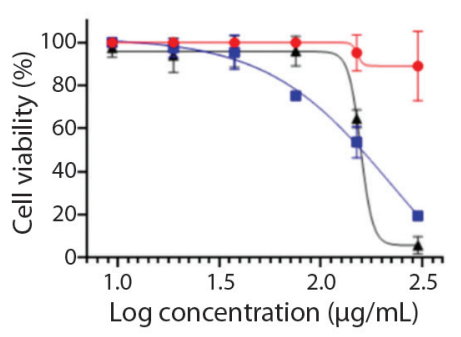

C Dichloromethane

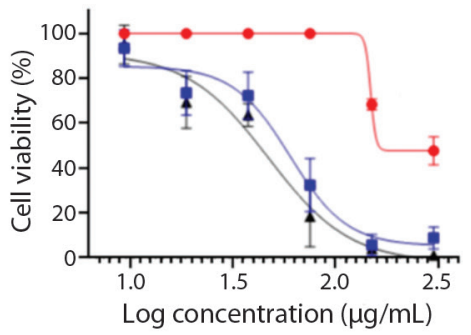

E

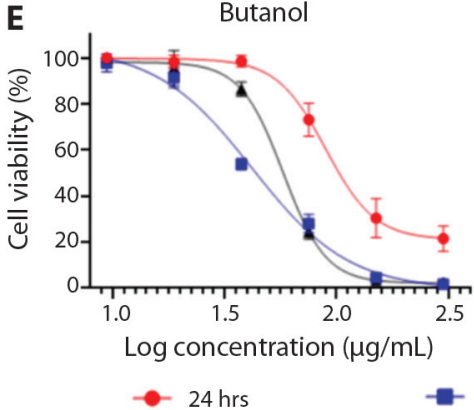

B

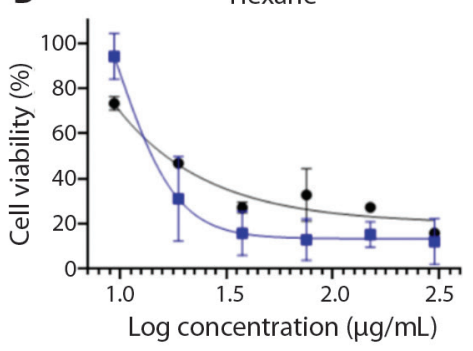

D

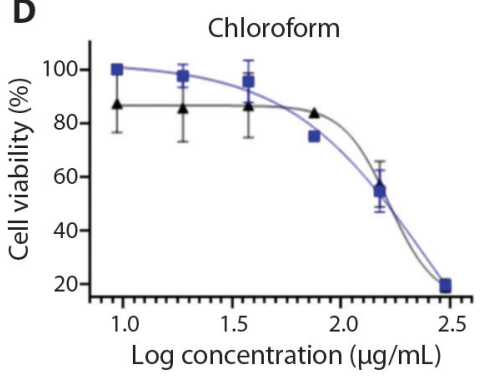

$\mathbf{F}$



Fig. 2. In vitro cytotoxic activity of various extracts in MCF-7 cells (Human breast cancer cells) by SRB assay at different times of exposure (24, 48 and 72 hours). All the values are mean \pm SD of three samples. A. $80 \%$ Ethanolic extract, B. Hexane, C. Dichloromethane, D. Chloroform, E. Butanol, F. Aqueous fraction.

microscope (Olympus, CKX41) at $4 \mathrm{X}$ and 10X magnification. MCF-7 and MCF10A cells treated with various extract/fractions and then observed after $72 \mathrm{~h}$ incubation (Fig. 3). The results only showed for hexane (Fig. 3A, Fig. 3D, Fig. 3G), DCM (Fig. 3B, Fig. 3E, Fig. 3H) and butanol (Fig. 3C, Fig. 3F, Fig. 3I) fractions.

Significant phenotypic differences were observed in the presence of Senna alata extracts as cancer cell line was incubated (Fig. 3). From cell photographs at first day (24 hours) that the cells treated with fractions in Fig. 3B and Fig. 3C the cells and their volume started to decrease and round shape in contrast to the control of the MCF-7 cells treated with Tamoxifen which were a simple function of apoptosis (figure not shown). After 48 and 72 hours, cells became cluster together, exhibited membrane blebbing (Fig. 3D, Fig. 3E, Fig. 3F, $48 \mathrm{hrs}$ ), and began to detach from the dish (Fig. 3H, Fig. 3I, 72 hrs). Normal MCF10A cells, by contrast, have not shown those significant morphologic changes (data not shown). This indicates that $S$. alata is effective and reasonably non-toxic for folk/conventional drugs and appropriate for cancer treatment. 


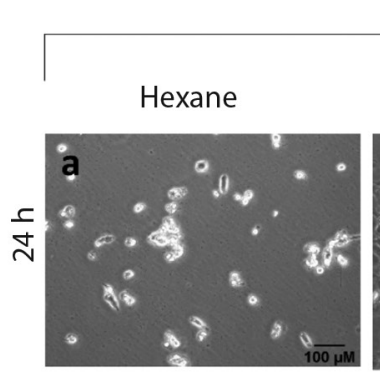

\section{DCM}
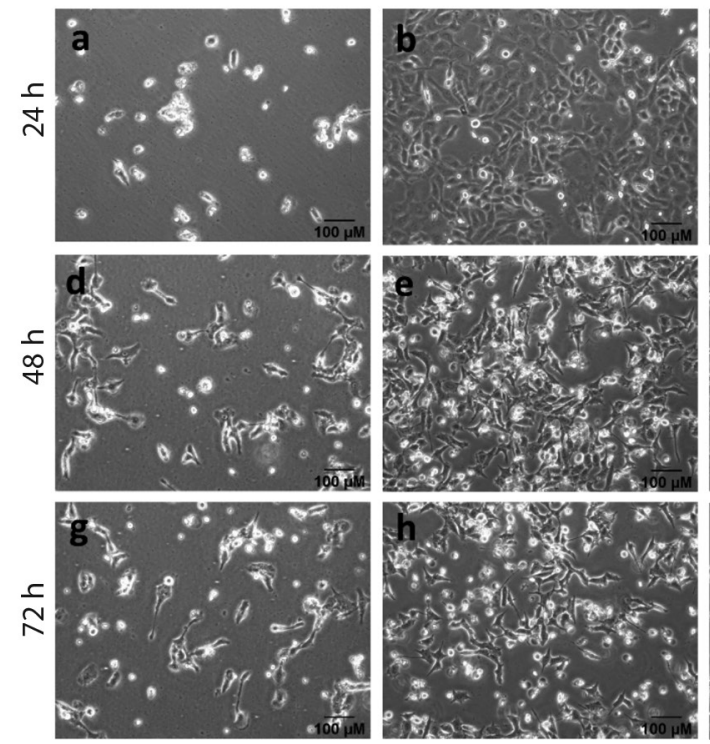

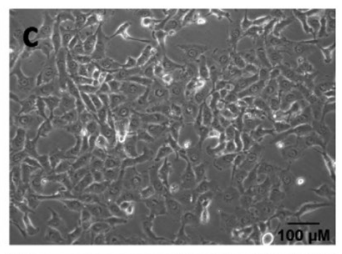

$72 \mathrm{~h}$
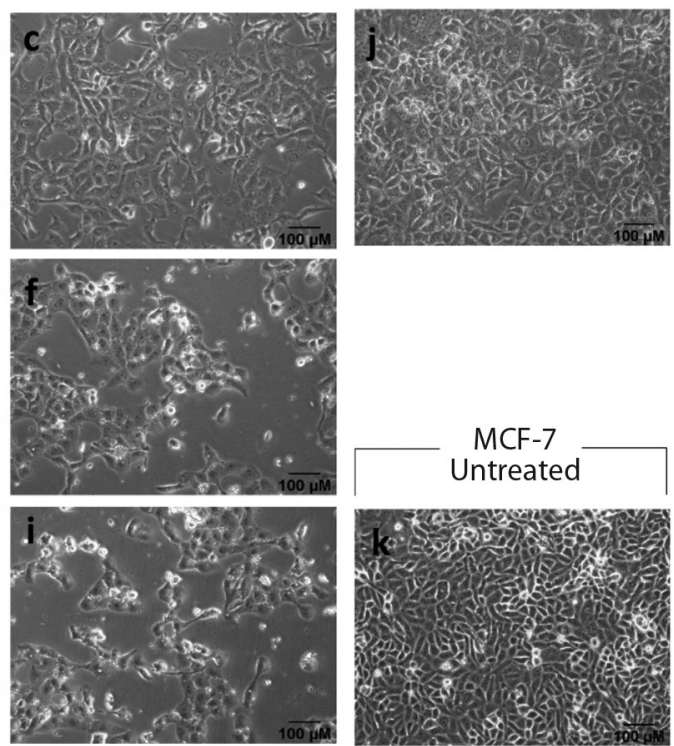

Fig. 3. Morphological changes of MCF-7 and MCF10A cells treated with extract/fractions of Senna alata L. during 24, 48 and $72 \mathrm{~h}$. $\mathrm{IC}_{50}$ calculated with the SRB assay evaluating dose-responsive curves. Various cell forms shown on MCF-7 and MCF10A, treated with S. alata during $72 \mathrm{~h}$. Vehicle DMSO is used to treat control cells. A. MCF-7 cells with hexane treatment at $24 \mathrm{hrs}$; B. Cells with dichloromethane treatment at $24 \mathrm{hrs}$; C. MCF-7 cells with butanol treatment at $24 \mathrm{hrs;}$ D. MCF-7 cells with hexane treatment at $48 \mathrm{hrs;} \mathrm{E.} \mathrm{MCF-7} \mathrm{cells} \mathrm{with} \mathrm{dichloromethane} \mathrm{treatment} \mathrm{at} 48$ hrs; F. MCF-7 cells with butanol treatment at $48 \mathrm{hrs}$; G. MCF-7 cells with hexane treatment at $72 \mathrm{hrs}$; H. MCF-7 cells with dichloromethane treatment at $72 \mathrm{hrs}$; I. MCF-7 cells with butanol treatment at $72 \mathrm{hrs;} \mathrm{J.} \mathrm{MCF10A} \mathrm{cells} \mathrm{untreated} \mathrm{as} \mathrm{control} \mathrm{after} 72 \mathrm{hrs;}$ and K. MCF-7 cells untreated as a control after 72 hrs.

\section{DISCUSSION}

Breast cancer is the world's second most fatal illness for women (Kamalanathan \& Natarajan, 2018). Several other findings have shown that numerous medicinal plants can be used to prevent the growth of human breast cancer (Kamalanathan \& Natarajan, 2018). However, a collection of antioxidant compounds exists in herbs, fruits and plants have already shown that breast cancer cells are destroyed by them without no toxic effect on normal cells (Raj, Ireland, Ouhtit, Gaur, \& Abdraboh, 2015). Both BSLT and ABTS (antioxidant assay) are easy to handle, low cost, and use small quantities of test equipment (Peteros \& Uy, 2010; Asnaashari et al., 2017). The ABTS radical-scavenging measuring technique, a popular method utilized to test the antioxidant activity, gains from adopting a hydrogen ion from the antioxidant, decolorizing its blue colors, as ABTS free radicals become steady (Lee, Oh, Cho, \& Ma, 2015). The ABTS assay seems to be more sensitive than DPPH assay in detecting antioxidant activity due to extreme faster reaction kinetics, and its reaction to antioxidants is stronger (Lee et al., 2015), and The ABTS radical is significantly more water-soluble than DPPH (He et al., 2010). Although the antioxidant activity of leaf extract from $S$. alata fractionation obtained a new indole alkaloid, 1-(4'-hydroxyphenyl)2,4,6-trihydroxy-indole-3-carboxylic acid that exhibited strong antioxidant potential with an $\mathrm{IC}_{50}$ of $0.0311 \mu \mathrm{M} \pm 0.002$ (Olarte, Herrera, Villasenor, \& Jacinto, 2010). In other study, ethanol extract from leaves of this plant showed $67 \%$ of the antioxidant activity (Sagnia 
et al., 2014). Also, the hexane extract of $S$. alata showed no free radical scavenging activity (Jacinto, Olarte, Galvez, Villasenor, \& Pezzuto, 2005). To identify bioactive compounds from $80 \%$ ethanolic extract of S. alata, our GC-MS result confirmed the study by Ali et al. (2017), which found the same compounds mostly, fatty acids composition from leaves of Senna alata (Ali et al., 2017).

It indicated that the brine shrimp lethality test was helpful in assessing the toxicity of the plant extract (Sahgal et al., 2010). This procedure involves exposure of brine shrimp larvae to plant extract in saline media, and the death of larvae is measured after one day (Mayilsamy \& Geetharamanan, 2016). Logarto has shown that a strong link was found between the $\mathrm{LC}_{50}$ of the brine shrimp lethality test and $\mathrm{LD}_{50}$ in the acute oral toxicity test in mice $(\mathrm{r}=0.85 ; P$ $<0.05$ ) (Logarto et al., 2001). Upon 24 hours of treatment, Artemia salina larvae with $\mathrm{LC}_{50}$; if the sample extract is $\mathrm{LC}_{50}<1000 \mu \mathrm{g} / \mathrm{mL}$, its toxicity is high, and the cytotoxicity is expected to occur. The level of toxicity would have an anticancer effect on extracts (Prasetyo et al., 2019). Evaluating the efficiency of hatching cysts concerning the time of exposure showed that extracts had notable hatching success after 36-48 hours, which would be the greatest hatching time for brine shrimp (Meyer et al., 1982; Braguini, Pires, \& Alves, 2018).

The method of Meyer et al., graded as toxic $\left(\mathrm{LC}_{50}\right.$ value $\left.<1000 \mu \mathrm{g} / \mathrm{mL}\right)$ and non-toxic $\left(\mathrm{LC}_{50}\right.$ value $\left.>1000 \mu \mathrm{g} / \mathrm{mL}\right)$ for crude extracts and pure materials (Meyer et al., 1982; Naher et al., 2019). Another study revealed that seed extract showed more toxic than leaf extract of S. alata showed $\mathrm{LC}_{50}$ value at 4.31 and 5.29 ppm, respectively, from the result of the brine shrimp lethality test (Rahman, 2004). Also, the $\mathrm{LC}_{50}$ value of the $C$. alata seed oil extract was at $250 \mu \mathrm{g} / \mathrm{mL}$ (Mannan et al., 2011), and $7.74 \mu \mathrm{g} / \mathrm{mL}$ (Parra, Yhebra, Sardiñas, \& Buela, 2001). This suggests that these fractions may contain no cytotoxic compound. Brine shrimp mortality was predicted to be related to bioactive compounds and not malnutrition after exposure to dichloromethane, chloroform, butanol, and aqueous fractions. However, the percentage of deaths as time and concentration was increased for these fractions and the existence of toxic compounds in the fractions, which requires further examination, may lead to that effect. Several studies showed a strong correlation with different tumor cell lines in the BSLT (Elsyana et al., 2016). In BSLT, the cytotoxicity activity of the extract is determined by a $50 \%$ death response to brine shrimp $\left(\mathrm{LC}_{50}\right)$ (Elsyana et al., 2016). Based on our hexane fraction results from MCF-7 cell line, and according to Elsyana et al., compared this fraction with other extracts and fractions containing flavonoids and triterpenoids, the maximum cytotoxic activity was reported by hexane fraction (Elsyana et al., 2016). Also, Olarte and colleagues (Olarte et al., 2013) found out that the hexane extract from $S$. alata showed the highest growth inhibition against MCF-7 cell line among three other extracts with $\mathrm{IC}_{50}$ value $16 \mu \mathrm{g} / \mathrm{mL}$ which confirm our present study with $\mathrm{IC}_{50}$ values 9.63 and $0.01 \mu \mathrm{g} / \mathrm{mL}$ for 48 and 72 hrs, respectively. However, based on the National Cancer Institute guideline (NCI, USA) that $30 \mu \mathrm{g} / \mathrm{mL}$ is the higher $\mathrm{IC}_{50}$ ranges assumed reasonable for purification of an extract (Akindele et al., 2015). Another study revealed that hexane fraction of $S$. alata possessed cytotoxic effect against lung cancer cell (A549) and ovarian cancer cells (OV2008) (Levy \& Carley, 2012). Also, ethyl acetate extract of $S$. alata by other studies showed 50 $\%$ inhibition $\left(\mathrm{GI}_{50}\right)$ value at $5.90 \mu \mathrm{g} / \mathrm{mL}$ against the MCF-7 cell line (Onyegeme-Okerenta, 2018). On the other hand, the chloroform fraction showed anticancer activity against MCF-7 with $\mathrm{IC}_{50}$ value $37.4 \mu \mathrm{g} / \mathrm{mL}$ (Ali et al., 2017). According to other studies, chloroform extract from the stem of three species from Cassia sp., namely, C. glauca, C. obtusifolia and C. sophera showed high cytotoxicity against MCF-7 cell line (Shankar \& Surekha, 2017). Emodin was previously separated from $S$. alata leaves (Prasenjit et al., 2016; Ali et al., 2017) and showed anticancer activity (Hsu \& Chung, 2012). These findings revealed that there is a direct connection between the brine shrimp 
lethality test and in vitro cytotoxicity towards the $S$. alata extracts. In the present study, we displayed that hexane and butanol fractions induce apoptosis in MCF-7 human breast cells in a time- and concentration-dependent basis, which is similar with previous studies using different extracts of $S$. alata (Olarte et al., 2013; Onyegeme-Okerenta, 2018). Our finding indicates that $S$. alata extracts cytotoxicity is performed through apoptotic cell death in tumor cells. In a study by Olarte and colleagues that they treated hexane fraction with MCF-7 cell line. The MCF-7 cells rounded up and missed contact with adjacent cells between 12-24 hrs (Olarte et al., 2013).

The anticancer function of flavonoids and triterpenoids, according to their antioxidant characteristics, is consistent with their capacity to scavenge free radicals, to suppress radical oxygen species (ROS), enzymes and to prevent cells and extracellular compound oxidation (Elsyana et al., 2016). Flavonoids and triterpenoids were concentration-dependent toxic to the brine shrimp and, therefore, could have resulted in the death of brine shrimp (Elsyana et al., 2016). Several studies have shown that flavonoids can prevent the proliferation and delay of tumor cells (Razak et al., 2019). Assessment of bioactive compounds such as flavonoids, alkaloids, glycosides, carbohydrates, protein, saponins, triterpenoids, and amino acids indicated the existence of most of the component in polar extracts such as ethanol, methanol and aqueous extracts comparison with nonpolar extracts such as petroleum ether and chloroform. Though, all extracts possessed flavonoids, phenols, and tannins (Panda et al., 2011). Because of its perfect fundamental chemistry to free radical scavenging activities, phenols are a significant class of antioxidants (Chaudhary et al., 2015). However, S. alata extracts showed potential cancer cell inhibition and reduced the risk of further proliferation based on the results of the SRB assay. Jacinto et al. (2005) identified a high cancer chemo preventive ability while $S$. alata hexane leaf extract was found to cause a particular activity of the quinone reductase similar to the bromoflavone as a chemo preventive agent (Jacinto et al., 2005). More pharmacological and phytochemical tests are worthwhile in this research to establish the exact principal cytotoxicity compound reaction.

The result of this study shows $S$. alata could be an outstanding lead in the progress of breast cancer anticancer agents $\left(\mathrm{IC}_{50}<100 \mu \mathrm{g} /\right.$ $\mathrm{mL}$ ), which did not exhibit toxicity on normal cell line as well. Interestingly, in contrast to SRB assay results, the $S$. alata extract/fractions exhibited non-toxic activity $\left(\mathrm{LC}_{50}>1000\right.$ $\mu \mathrm{g} / \mathrm{mL}$ ) was assessing using the brine shrimp lethality test as a primary assay for anticancer activity. The source of organic antioxidants is available and provides significant medical benefits. It could be inferred from GC-MS findings that $S$. alata contains many bioactive compounds. Our laboratory is also investigating further research to clarify the mechanism of action of apoptosis in breast cancer and bioactive compounds, which will be published in a future manuscript.

Ethical statement: authors declare that they all agree with this publication and made significant contributions; that there is no conflict of interest of any kind; and that we followed all pertinent ethical and legal procedures and requirements. All financial sources are fully and clearly stated in the acknowledgements section. A signed document has been filed in the journal archives.

\section{ACKNOWLEDGMENTS}

This study was supported in part by the FRGS grant (203.CIPPT.6711684) from Ministry of Education (MOE) Government of Malaysia.

\section{RESUMEN}

Baja citotoxicidad, y actividad antiproliferativa sobre las células cancerosas, de la planta Senna alata (Fabaceae). Introducción: Las hojas de Senna alata de la familia Fabaceae se han utilizado en la medicina popular para la cura de enfermedades de la piel. En este estudio, 
probamos el extracto de la planta en líneas celulares normales y cancerosas. Objetivo: Evaluamos la citotoxicidad de S. alata usando una prueba del camarón Artemia y la actividad antiproliferativa. Métodos: El extracto de hoja etanólico al $80 \%$ y sus fracciones se examinaron en busca de un posible efecto citotóxico utilizando un ensayo de citotoxicidad de sulforrodamina B (SRB) frente a líneas celulares de cáncer de mama (MCF-7), normales (MCF10A) y prueba de letalidad del camarón Artemia (BSLT). Resultados: El bioensayo de letalidad del camarón Artemia no presenta citotoxicidad incluso en alta concentración $(5000 \mu \mathrm{g} / \mathrm{mL})$. La CL50 para diclorometano, cloroformo, butanol y acuoso fue $>1000 \mu \mathrm{g} / \mathrm{mL}$ (no tóxico). La CI50 para la citotoxicidad in vitro de SRB contra MCF-7 para n-hexano fue de $0.013 \mu \mathrm{g} / \mathrm{mL}$, que se consideró altamente tóxica, mientras que el diclorometano y el cloroformo registraron $47.11 \mathrm{y}$ $57.61 \mu \mathrm{g} / \mathrm{mL}$, respectivamente, después de 72 horas de tiempo de exposición, aunque no hubo citotoxicidad encontrada en la línea celular normal. Conclusión: Este estudio muestra que el extracto de hoja etanólico crudo de $S$. alata y sus fracciones contienen potencialmente compuestos bioactivos significativos que están a salvo de efectos adversos, lo que demuestra la aplicación terapéutica de $S$. alata como remedio tradicional.

Palabras clave: citotoxicidad; Artemia; Senna alata; cáncer de mama.

\section{REFERENCES}

Abatan, M.O. (1990). A note on the anti-inflammatory action of plants of some Cassia species. Fitoterapia, 61, 336-338.

Akindele, A.J., Wani, Z.A., Sharma, S., Mahajan, G., Satti, N.K., Adeyemi, O.O., . . . Saxena, A.K. (2015). In vitro and In vivo anticancer activity of root extracts of Sansevieria liberica gerome and labroy (Agavaceae). Evidence-Based Complementary and Alternative Medicine, 2015, 560404. DOI: 10.1155/2015/560404

Al-Ansari, M., Al-Humaid, L.A., Vijayaraghavan, P., Ravindran, B., Chang, S.W., Agastian, P., . . Balamuralikrishnan, B. (2019). Identification of phytochemical components from Aerva lanata (Linn.) medicinal plants and its in-vitro inhibitory activity against drug resistant microbial pathogens and antioxidant properties. Saudi Journal of Biological Sciences, 26(6), 1129-1133. DOI: 10.1016/j.sjbs.2019.02.010

Ali, M.I., Aboul-Enein, A.M., Mohamed, S.M., Elella, F.M.A., Mohammed, M.M.D., \& Hamed, A.R. (2017). Phytochemical, cytotoxicity and antioxidant investigation of Cassia alata leaves growing in Egypt. Journal of Innovations in Pharmaceutical and Biological Sciences (JIPBS), 4(4), 97-105.

Asnaashari, S., Delazar, A., Asgharian, P., Lotfipour, F., Moghaddam, S.B., \& Afshar, F.H. (2017). In-vitro bioactivity and phytochemical screening of extracts from rhizomes of Eremostachys azerbaijanica rech. f. growing in Iran. Iranian Journal of Pharmaceutical Research, 16(1), 306-314.

Azamjah, N., Soltan-Zadeh, Y., \& Zayeri, F. (2019). Global trend of breast cancer mortality rate: A 25-year study. Asian Pacific Journal of Cancer Prevention, 20(7), 2015-2020. DOI: 10.31557/APJCP.2019.20.7.2015

Beutler, J.A. (2019). Natural products as a foundation for drug discovery. Current Protocols in Pharmacology, 86(1), e67. DOI: 10.1002/cpph.67

Braguini, W.L., Pires, N.V., \& Alves, B.B. (2018). Phytochemical analysis, antioxidant properties and brine shrimp lethality of unripe fruits of Solanum viarum. Journal of Young Pharmacists, 10(2), 159-163.

Chaudhary, S., Chandrashekar, K.S., Pai, K.S.R., Setty, M.M., Devkar, R.A., Reddy, N.D., \& Shoja, M.H. (2015). Evaluation of antioxidant and anticancer activity of extract and fractions of Nardostachys jatamansi DC in breast carcinoma. BMC Complementary and Alternative Medicine, 15(1), 50. DOI: 10.1186/ s12906-015-0563-1

Elsyana, V., Bintang, M., \& Priosoeryanto, B.P. (2016). Cytotoxicity and antiproliferative activity assay of Clove Mistletoe (Dendrophthoe pentandra (L.) Miq.) Leaves Extracts. Advances in Pharmacological Sciences, 2016, 3242698. DOI: 10.1155/2016/3242698

Fernand, V.E., Dinh, D.T., Washington, S.J., Fakayode, S.O., Losso, J.N., van Ravenswaay, R.O., \& Warner, I.M. (2008). Determination of pharmacologically active compounds in root extracts of Cassia alata L. by use of high-performance liquid chromatography. Talanta, 74(4), 896-902. DOI: $10.1016 / \mathrm{j}$. talanta.2007.07.033

GraphPad Software. (1996). GraphPad Prism version 8.00 for Windows. Retrieved from https://www.graphpad. com/scientific-software/prism

He, W., Liu, X., Xu, H., Gong, Y., Yuan, F., \& Gao, Y. (2010). On-line HPLC-ABTS screening and HPLCDAD-MS/MS identification of free radical scavengers in Gardenia (Gardenia jasminoides Ellis) fruit extracts. Food Chemistry, 123(2), 521-528.

Hennebelle, T., Weniger, B., Joseph, H., Sahpaz, S., \& Bailleul, F. (2009). Senna alata. Fitoterapia, 80(7), 385-393. DOI: 10.1016/j.fitote.2009.05.008

Henry, Y.W. (2017). Brine Shrimp Cytotoxic Activity of Morinda elliptica Leaves and Root Crude Extracts. Borneo Journal of Resource Science and Technology, 7(1), 43-46. DOI: 10.33736/bjrst.390.2017

Heyde, H. (1990). Medicinal plants in Suriname. Paramaribo, Suriname: Mungra \& Madarie. 
Hsu, S.C., \& Chung, J.G. (2012). Anticancer potential of emodin. BioMedicine, 2(3), 108-116. DOI: 10.1016/j. biomed.2012.03.003

Ibrahim, D., \& Osman, H. (1995). Antimicrobial activity of Cassia alata from Malaysia. Journal of Ethnopharmacology, 45(3), 151-156. DOI: 10.1016/0378-8741(94)01200-J

Idris, O.A., Wintola, O.A., \& Afolayan, A.J. (2019). Evaluation of the bioactivities of Rumex crispus L. leaves and root extracts using toxicity, antimicrobial, and antiparasitic assays. Evidence-Based Complementary and Alternative Medicine, 2019, 6825297. DOI: $10.1155 / 2019 / 6825297$

Igoli, J.O., Igwue, I.C., \& Igoli, N.P. (2004). Traditional medicinal practices among the Igede people of Nigeria. Journal of Herbs, Spices \& Medicinal Plants, 10(4), 1-10. DOI: 10.1300/J044v10n04_01

Iyengar, M.A., Rama, M.P., \& Rao, G. (1995). Antifungal activity of Cassia alata, leaf extract. Indian Drugs, 32(5), 230-231.

Jacinto, S.D., Olarte, E.I., Galvez, M., Villasenor, I.M., \& Pezzuto, J.M. (2005). Leaf extracts from Cassia alata L. ("Akapulko") induces quinone reductase and competes for estrogen receptor binding indicating cancer chemopreventive property. Philippine Agricultural Scientist, 88(2), 175-178.

Kamalanathan, D., \& Natarajan, D. (2018). Anticancer potential of leaf and leaf-derived callus extracts of Aerva javanica against MCF-7 breast cancer cell line. Journal of Cancer Research and Therapeutics, 14(2), 321-327. DOI: 10.4103/0973-1482.171210

Kanthal, L.K., Dey, A., Satyavathi, K., \& Bhojaraju, P. (2014). GC-MS analysis of bio-active compounds in methanolic extract of Lactuca runcinata DC. Pharmacognosy Research, 6(1), 58-61. DOI: 10.4103/0974-8490.122919

Karchesy, Y.M., Kelsey, R.G., Constantine, G., \& Karchesy, J.J. (2016). Biological screening of selected Pacific Northwest forest plants using the brine shrimp (Artemia salina) toxicity bioassay. Springerplus, 5, 510. DOI: 10.1186/s40064-016-2145-1

Khan, M.R., Kihara, M., \& Omoloso, A.D. (2001). Antimicrobial activity of Cassia alata. Fitoterapia, 72(5), 561-564. DOI: 10.1016/S0367-326X(00)00335-X

Lee, K.J., Oh, Y.C., Cho, W.K., \& Ma, J.Y. (2015). Antioxidant and anti-Inflammatory activity determination of one hundred kinds of pure chemical compounds using offline and online screening HPLC assay. EvidenceBased Complementary and Alternative Medicine, 2015, 165457. DOI: 10.1155/2015/165457

Levitsky, D.O., \& Dembitsky, V.M. (2014). Anti-breast cancer agents derived from plants. Natural Products and Bioprospecting, 5(1), 1-16. DOI: 10.1007/ s13659-014-0048-9

Levy, A.S., \& Carley, S. (2012). Cytotoxic activity of hexane extracts of Psidium guajava L (Myrtaceae) and Cassia alata L (Caesalpineaceae) in Kasumi-1 and OV2008 cancer cell lines. Tropical Journal of Pharmaceutical Research, 11(2), 201-207.

Logarto, A., Silva, R., Guerra, I., \& Iglesias, L. (2001). Comparative study of the assay of Artemia salina L. and the estimate of the medium lethal dose (LD50 value) in mice, to determine oral acute toxicity of plant extracts. Phytomedicine, 8(5), 395-400. DOI: 10.1078/0944-7113-00044

Mannan, A., Kawser, M.J., Ahmed, A.A., Islam, N.N., Alam, S.M., Khan, M.A.E., \& Gupta, S.D. (2011). Assessment of antibacterial, thrombolytic and cytotoxic potential of Cassia alata seed oil. Journal of Applied Pharmaceutical Science, 1(9), 56.

Mayilsamy, M., \& Geetharamanan, K. (2016). Cytotoxic activity of certain medicinal plants extracts against sea monkey: Artemia salina. Journal of Medicinal Herbs and Ethnomedicine, 2, 19-25.

McLaughlin, J.L., Rogers, L.L., \& Anderson, J.E. (1998). The use of biological assays to evaluate botanicals. Drug Information Journal, 32(2), 513-524. DOI: $10.1177 / 009286159803200223$

Meyer, B.N., Ferrigni, N.R., Putnam, J.E., Jacobsen, L.B., Nichols, D.E., \& McLaughlin, J.L. (1982). Brine shrimp: a convenient general bioassay for active plant constituents. Planta Medica, 45(5), 31-34. DOI: $10.1055 / \mathrm{s}-2007-971236$

Mohanraj, K., Karthikeyan, B.S., Vivek-Ananth, R.P., Chand, R.P.B., Aparna, S.R., Mangalapandi, P., \& Samal, A. (2018). IMPPAT: A curated database of Indian medicinal plants, phytochemistry and therapeutics. Scientific Reports, 8(1), 4329. DOI: 10.1038/ s41598-018-22631-z

Naher, S., Aziz, M.A., Akter, M.I., Rahman, S.M.M., Sajon, S.R., \& Mazumder, K. (2019). Anti-diarrheal activity and brine shrimp lethality bioassay of methanolic extract of Cordyline fruticosa (L.) A. Chev. leaves. Clinical Phytoscience, 5(1), 15. DOI: 10.1186/ s40816-019-0109-z

Olarte, E.I., Herrera, A.A., Villasenor, I.M., \& Jacinto, S.D. (2010). Antioxidant activity of a new indole alkaloid from Cassia alata L. Philippine Agricultural Scientist, 93(3), 250-254.

Olarte, E.I., Herrera, A.A., Villasenor, I.M., \& Jacinto, S.D. (2013). In vitro antitumor properties of an isolate from leaves of Cassia alata L. Asian Pacific Journal of Cancer Prevention, 14(5), 3191-3196.

Onyegeme-Okerenta, B. (2018). Ethyl acetate extract of Senna alata (L) Roxb increases cytotoxicity in the 
human breast, prostate and colorectal cancer cells. Journal of Cancer Treatment and Research, 6(3), 44-53.

Palanichamy, S., Bhaskar, E.A., Bakthavathsalam, R., \& Nagarajan, S. (1991). Wound healing activity of Cassia alata. Fitoterapia, 62(1), 153-156.

Palanichamy, S., \& Nagarajan, S. (1990). Antifungal activity of Cassia alata leaf extract. Journal of Ethnopharmacology, 29(3), 337-340. DOI: 10.1016/0378-8741(90)90043-S

Pamulaparthi, A., \& Nanna, R.S. (2015). Determination of anticancer activity of aqueous leaf extracts of Senna alata using MTT assay. Journal of Cancer Science and Therapy, 7, 10. DOI: 10.4172/1948-5956.C1.055

Panda, S.K., Padhi, L.P., \& Mohanty, G. (2011). Antibacterial activities and phytochemical analysis of Cassia fistula (Linn.) leaf. Journal of Advanced Pharmaceutical Technology \& Research, 2(1), 62-67. DOI: 10.4103/2231-4040.79814

Parra, A.L., Yhebra, R.S., Sardiñas, I.G., \& Buela, L.I. (2001). Comparative study of the assay of Artemia salina $\mathrm{L}$. and the estimate of the medium lethal dose (LD50 value) in mice, to determine oral acute toxicity of plant extracts. Phytomedicine, 8(5), 395-400.

Peteros, N.P., \& Uy, M.M. (2010). Antioxidant and cytotoxic activities and phytochemical screening of four Philippine medicinal plants. Journal of Medicinal Plants Research, 4(5), 407-414.

Prasenjit, M., Tanaya, G., Sumanta, G., Basudeb, B., \& Kumar, M.P. (2016). Isolation and characterization of a compound from the leaves of Cassia alata Linn. ECronicon Chemistry, 2(2), 138-144.

Prasetyo, A., Sidharta, B.R., Hartini, Y.S., \& Mursyanti, E. (2019). Toxicity of bioactivity compound from endophytic fungi isolated from red ginger (Zingiber officinale var. rubrum) utilizing brine shrimp lethality assay. Biogenesis: Jurnal Ilmiah Biologi, 7(1), 30-37. DOI: $10.24252 /$ bio.v7i1.6000

Promgool, T., Pancharoen, O., \& Deachatai, S. (2014). Antibacterial and antioxidative compounds from Cassia alata Linn. Songklanakarin Journal of Science and Technology, 36(4), 459-463.

Rahman, Ì. (2004). Brine shrimp toxicity of leaf and seed extracts of Cassia alata Linn, and their antibacterial potency. Journal of Medical Sciences, 4(3), 188-193.

Raj, M., Ireland, S., Ouhtit, A., Gaur, R., \& Abdraboh, M. (2015). Complementary/alternative medicine strategies for prevention and or cure of breast cancer: a review. Women's Health International, 1(2), 111.
Razak, N.A., Abu, N., Ho, W.Y., Zamberi, N.R., Tan, S.W., Alitheen, N.B., ... Yeap, S.K. (2019). Cytotoxicity of eupatorin in MCF-7 and MDA-MB-231 human breast cancer cells via cell cycle arrest, anti-angiogenesis and induction of apoptosis. Scientific Reports, 9(1), 1514. DOI: 10.1038/s41598-018-37796-w

Re, R., Pellegrini, N., Proteggente, A., Pannala, A., Yang, M., \& Rice-Evans, C. (1999). Antioxidant activity applying an improved ABTS radical cation decolorization assay. Free Radical Biology and Medicine, 26(9-10), 1231-1237. DOI: 10.1016/ s0891-5849(98)00315-3

Sagnia, B., Fedeli, D., Casetti, R., Montesano, C., Falcioni, G., \& Colizzi, V. (2014). Antioxidant and anti-inflammatory activities of extracts from Cassia alata, Eleusine indica, Eremomastax speciosa, Carica papaya and Polyscias fulva medicinal plants collected in Cameroon. PLoS One, 9(8), e103999. DOI: 10.1371/ journal.pone.0103999

Sahgal, G., Ramanathan, S., Sasidharan, S., Mordi, M.N., Ismail, S., \& Mansor, S.M. (2010). Brine shrimp lethality and acute oral toxicity studies on Swietenia mahagoni (Linn.) Jacq. seed methanolic extract. Pharmacognosy Research, 2(4), 215-220. DOI: 10.4103/0974-8490.69107

Saito, S.T., Trentin, S., Macedo, A.J., Pungartnik, C., Gosmann, G., Silveira, D., . . Brendel, M. (2012). Bioguided fractionation shows Cassia alata Extract to inhibit Staphylococcus epidermidis and Pseudomonas aeruginosa growth and biofilm formation. Evidence-Based Complementary and Alternative Medicine, 2012, 867103. DOI: 10.1155/2012/867103

Shankar, B.N., \& Surekha, R.D. (2017). Cytotoxicity of stem extracts of selected Cassia species against Hela and breast cancer cell lines in vitro. Asian Journal of Pharmaceutical and Clinical Research, 10(3), 80-82. DOI: 10.22159/ajpcr.2017.v10i3.11991

Shareef, M., Ashraf, M.A., \& Sarfraz, M. (2016). Natural cures for breast cancer treatment. Saudi Pharmaceutical Journal, 24(3), 233-240. DOI: 10.1016/j. jsps.2016.04.018

Tene, O., Tala, V.R.S., Tatong, N., \& Tchuente, K. (2017). Ethnobotanical uses, phytochemical and pharmacological profiles, and toxicity of Cassia alata L. An overview. Medicine and Medical Sciences, 4(2), 16-24.

Yagi, S.M., Tigani, S.E., \& Adam, S.E.I. (1998). Toxicity of Senna obtusifolia fresh and fermented leaves (kawal), Senna alata leaves and some products from Senna alata on rats. Phytotherapy Research, 12(5), 324-330. DOI: 10.1002/(sici)10991573(199808)12:5<324::Aid-ptr300>3.0.Co;2-2 